\title{
CONSTITUTIONAL CHECKS ON COLLUSIVE INVASION OF JURISDICTION IN MATRIMONIAL ACTIONS
}

\begin{abstract}
THE INCREASING POPULARITY of the Virgin Islands as a 1 divorce haven ${ }^{1}$ and the legal problems connected therewith have been discussed in the Spring, 1953, issue of this Journal, ${ }^{2}$ where the conclusion was drawn that ". . . those with Virgin Islands divorces will be subject to the perils of shaky and uncertain marital status."3 The recent decision of the Court of Appeals for the Third Circuit in Alton v. Alton ${ }^{4}$ has done much to focus the attention of legal writers once more on the thorny issue of migratory divorces; ${ }^{5}$ and although the United States Supreme Court disposed of that case by simply vacating and remanding, it will come to grips with the issues involved in the not too distant future. ${ }^{6}$

It is the purpose of this Comment to discuss, by adverting to the Third Circuit's decision, the control exercised by the Federal Constitution over state and territorial power to grant divorces, and to draw attention to a point likely to be of substantial importance in the future: the yawning gap between the full faith and credit $^{7}$ and due process ${ }^{8}$ clauses.
\end{abstract}

${ }^{1}$ Cf. Meisel, America's New Divorce Haven, Reader's Digest, Jan. 1953, p. xo2.

? Calloway, Legal Status of the Virgin Islands Divorces, 3 DukE B.J. 102 (1953).

${ }^{3} I d$. at Ixz. $\quad{ }^{207}$ F.2d 667 (3d Cir. 1953).

${ }^{5}$ See Paulsen, The Power to Divorce-Two Legislative Acts, 40 A.B.A.J. 330 (1954); Comment, 39 CoRnell L.Q. 293 (1954); Notes, 34 B.U.L. Rev. 2 I6 (1954), 54 Col. L. Rev. 415 (1954), 42 Geo. L.J. 450 ( 954 ), 22 GeO. WASH. L. Rev. 356 (1954), 67 Harv. L. ReV. 516 (1954).

${ }^{\circ}$ In Alton v. Alton, 347 U.S. 610 (1954), the Supreme Court vacated the decision below because respondent had in the meantime obtained a divorce elsewhere and appellant had been a party to the latter proceeding. One month after the Supreme Court's decision, a case which "is the same with regard to all operative facts and principles of law" was decided in the same manner by the Third Circuit. GranvilleSmith v. Granville-Smith, 214 F.2d 820 (3d Cir. 1954). Certiorari has been granted: 22 U.S.L. WEEK 3082 (1954).

${ }^{7}$ U.S. Const. ART. IV, $\S_{1}$ : "Full Faith and Credit shall be given in each State to the public Acts, Records, and judicial Proceedings of every other State. And the Congress may by general Laws prescribe the Manner in which such Acts, Records and Proceedings shall be proved, and the Effect thereof."

${ }^{8}$ U.S. Const. AMend. V: "No person shall be . . . deprived of life, liberty, or property, without due process of law. ..." U.S. CoNST. AMEND. XIV, § 1 : ". . . Nor shall any State deprive any person of life, liberty, or property, without due process of law. ..." For applicability see note 15 infra. 
The facts of the Alton case are as follows: After six weeks' residence in the Virgin Islands, $W$, formerly domiciled in Connecticut, filed suit for divorce against $H$, also domiciled in Connecticut. $H$ entered appearance and waived service of summons without contesting $W$ 's allegations. The commissioner to whom the case was referred recommended that $W$ be granted a divorce for "incompatibility of temperament." The District Court for the Virgin Islands requested further proof of $W$ 's domicile; none forthcoming, it denied the relief sought. $W$ appealed, contending that, in accordance with Virgin Islands law, the court had no authority for further sua sponte inquiry. On appeal, $H$ filed no brief and made no argument. The district court's decision was affirmed by the Court of Appeals for the Third Circuit, sitting in banc (4:3), and the Virgin Islands statute on which $W$ relied was held unconstitutional.

This statute was an amendment to Section 9 of the Virgin Islands divorce law of 1944 which provided:

In an action for the dissolution of the marriage contract or for legal separation the plaintiff therein must be an inhabitant of the district at the commencement of the action for six weeks prior thereto, which residence shall be sufficient to give the Court jurisdiction without regard to the place where the marriage was solemnized or the cause of action arose. ${ }^{0}$

The words, "inhabitant" and "residence," having been held to mean "domiciliary" and "domicile" by way of dictum, ${ }^{10}$ the Legislative Assembly of the Virgin Islands ${ }^{11}$ enacted the following amendment:

Notwithstanding the provisions of sections 8 and 9 hereof, if the plaintiff is within the district at the time of the filing of the complaint and has been continuously for six weeks immediately prior thereto, this shall be prima facie evidence of domicile, and where the defendant has been personally served within the district or enters a general appearance in the action, then the Court shall have jurisdiction of the action and the parties thereto without further reference to domicile or to the place where the marriage was solemnized or the cause of action arose. ${ }^{12}$

${ }^{\circ}$ Law Concerning actions to Declare Void or Dissolve the Marriage ConTRACT, AND FOR OTHER PURPoses $\S 9$, approved December 29, 1944. The full text is quoted in Burch v. Burch, 195 F.2d 799, 802 n. 2 (3d Cir. 1952).

${ }^{10}$ Burch v. Burch, 195 F.2d 799, 804 (3d Cir. 1952).

11 Established pursuant to the Organic Act of June 22, 1936, 49 STAT. I 806, $1808-9$ (1936), 48 U.S.C. $\S$ r $405 f$ (1948).

${ }_{12}$ Bill No. 55, Legislative Assembly of the Virgin Islands, approved May 29, 1953 quoted in full in Alton v. Alton, 207 F.2d 667, 669 (3d Cir. 1953). 
Both portions of this amendment appear to be applicable to Mrs. Alton. Since she had been in the district for six weeks, she was entitled to the statutory presumption of being domiciled therein; and since Mr. Alton had entered a general appearance in the action, the court seemingly had jurisdiction of the action "without further reference to domicile." The reasons for the district court's denying $W$ 's motion to confirm the findings of the commissioner that she be granted a divorce are not quite clear but can possibly be gleaned from the following colloquy between the court and Mr. Dudley, W's counsel:

The Court: I have looked at the Transcript of the record herein and I would like to ask whether you have any more evidence to offer on the question of domicile.

Mr. Dudley: No, sir.

The Court: It is my opinion, after examining the record, that the proof herein is not sufficient to establish domicile in accordance with the directive in the case of Burch $v$. Burch, ${ }^{13}$ decided by the Court of Appeals of this Circuit.

Mr. Dudley: If your Honor please, our divorce law has been amended as of May 29, 1953, and there is a new section 9a now in effect which makes six weeks residence on the part of the plaintiff prior to the filing of the complaint prima facie evidence of domicile.

The Court: I have seen the new section and, as I said before, I doubt whether it is sufficient to confer jurisdiction, and I will have to deny your motion. The motion will therefore be denied and the complaint will be dismissed. ${ }^{14}$

Judge Goodrich's opinion affirming the decision of the district court, without offering reasons for the cavalier treatment of the 1953 amendment by the latter, treats the amendment as consisting of two logically distinct legal premises, and holds both to be unconstitutional as in contravention of the due process clauses of the Fifth Amendment and the Virgin Islands Organic Act.15 The legislative creation of a prima facie presumption of domicile on the basis of six weeks' physical presence is held to be unconstitutional as creating an unreasonable presumption with respect to a jurisdictional fact; and the automatic conferring of jurisdiction upon consent of the other party is treated as an unconstitu-

${ }^{13} 195$ F.2d 799 (3d Cir. 1952).

${ }^{14}{ }_{207}$ F.2d 667,684 ( ${ }_{3} \mathrm{~d}$ Cir. 1953 ) (dissenting opinion of Judge Hastie).

${ }^{15}$ Act of June 22, 1936, 49 STAT. I 806, I8 15 (1936), 48 U.S.C. § I406g (1948). The due process clause of the Fourteenth Amendment is not applicable to the Virgin Islands, since the Virgin Islands is no state. Cf. Alton v. Alton, 207 F.2d 667, 67o n. 8 ( 3 d Cir. 1953 ). 
tional interference with the domiciliaries of other states. There are thus two major issues: ( $\mathrm{r}$ ) whether the legislature can constitutionally create a prima facie presumption of domicile on the basis of a specified period of physical presence, assuming that domicile is a jurisdictional fact in divorce cases $;^{16}$ and (2) whether domicile of at least one of the parties within the jurisdiction of the court granting the divorce really is a constitutional requirement. This Comment is directed only to the latter.

\section{Domicile as a Constitutional Prerequisite of Divorce Jurisdiction}

It is ordinarily assumed that domicile of at least one party within the jurisdiction of the court granting a divorce decree is a constitutional prerequisite for its validity, even within the jurisdiction of the court granting it. As Judge Goodrich expressed it for the majority:

We think that the premise that divorce jurisdiction is founded on domicile is still the law. It was reiterated in [Williams $I I^{17}$ ]. If that premise is to disappear in the light of real or supposed change in social concepts, its disappearance should be the result of higher authority than ours. ${ }^{18}$

It is submitted, however, that especially on the basis of recent decisions of the United States Supreme Court, including the one relied on by Judge Goodrich, it is by no means clear that divorce jurisdiction has to be founded on domicile. A brief look at the Constitution and an analysis of recent Supreme Court decisions in the field of migratory divorces will disclose the reasons for this assertion.

Under the Constitution ${ }^{19}$ and legislation enacted in accordance therewith, ${ }^{20}$ judgments of the courts of states and territories ${ }^{21}$ of the Union are entitled to full faith and credit throughout the United States. They are only entitled to such full faith and credit, however, if granted by a

\footnotetext{
${ }^{16}$ The first attempt to lay down a general test for determining whether a statute making a fact presumptive evidence of another fact contravenes the due process cliuse came in Mobile J. \& K.C. R.R. v. Turnipseed, 2 Ig U.S. 35 (rgro) (statute making injury inflicted on persons by running locomotives or cars prima facie evidence of negligence held to be constitutional). See generally 9 WIGMORE, EvIDENCE $\$ 2.494$ (3d ed. 1940); Morgan, Further Observations on Presimptions, y6 CALIF. L. Rev. 245 (1953); Note, 56 HARv. L. REv. ${ }_{3} 24$ (1943).

${ }^{17}$ The reference is to Williams v. North Carolina (II), 325 U.S. 226, 229 (rg+5). See note 29 infra, and text at note 36 .

${ }^{18}{ }_{207}$ F.2d 667, 676 (3d Cir. x $_{953}$ ).

${ }^{10}$ See note 7 supra.

${ }_{20} 8$ U.S.C. $\$ 1738$ (Supp. 1952 ).

${ }^{21}$ The Virgin Islands is a territory, and the judgments of its courts are entitled to full faith and credit not on the basis of the Constitution, but on the basis of the statutory provision cited in note 20 supra.
} 
court having jurisdiction over both the subject-matter and the parties. If they meet these requirements, they must be given effect. That is the purpose-and the only purpose-of the full faith and credit clause. ${ }^{22}$ Under the various due process clauses, however, judgments not according procedural due process to both litigants are of no effect whatsover, even in the state of rendition..$^{23}$

It therefore appears to be at least logically possible that the two provisions of the Constitution governing jurisdiction and judgments within the Union are of entirely different scope and effect. The full faith and credit clause determines when the decision of the court of a sister state must be given effect; the due process clauses provide that all judicial decisions contrary to due process are of no effect whatsoever. But can a judgment, failing to meet the jurisdictional prerequisites of full faith and credit, nevertheless measure up to the due process mandates of the Constitution? The text is silent. And up to the present, the Supreme Court has decided only to what extent full faith and credit must be accorded divorces granted by sister states; it has not decided what types of divorce are invalid, even in the state of rendition. ${ }^{24}$

The question of full faith and credit has been involved in two fundamentally different types of divorce: (I) the so-called "ex parte" divorce, where only one party is subject to the personal jurisdiction of the court granting the divorce, and the other is served by publication or registered mail but does not appear or consent to service; and (2) what herein will be called the "normal" divorce, where the court granting the decree has personal jurisdiction over both parties.

With respect to ex parte divorces, the old, or Haddock, ${ }^{25}$ rule was that such divorces were not entitled to recognition in sister states under the full faith and credit clause. Such recognition could, nevertheless, be extended as a matter of comity; and the divorce was valid within the state of rendition. ${ }^{26}$ Thus, Mr. Haddock was single in Connecticut

${ }^{22}$ See Williams v. North Carolina (I), 317 U.S. 287, 293-295 (1942); Williams v. North Carolina (II), 325 U.S. 226, 227-229 (1945).

${ }^{33}$ Pennoyer v. Neff, 95 U.S. $7 \times 4$ (1878); International Shoe Co. v. Washington, 326 U.S. 310 (1945); Mullane v. Central Hanover Bank \& Trust Co., 339 U.S. 306 (1950).

${ }^{24}$ See notes 33 to 42 infra and accompanying text.

${ }^{25}$ Haddock v. Haddock, 20 I U.S. 562 (1906).

${ }^{20} I d$. at 605-606: "Without questioning the power of the State of Connecticut to enforce within its own borders the decree of divorce which is here in issue [granted to a Connecticut domiciliary against a New York domiciliary without appearance by the latter], and without intimating a doubt as to the power of the State of New York to give a decree of that characater rendered in Connecticut, within the borders of the State of New York and as to its own citizens, such efficacy as it may be entitled to in view of the public policy of that State, we hold that the decree of the court of Con- 
but married in New York; and Mrs. Haddock was in the same situation. It might be questioned whether this result was intended; ${ }^{27}$ certainly, there has hardly ever been a more universally disliked decision. ${ }^{28}$ It has, however, been formally and expressis verbis overruled in the memorable Williams cases, ${ }^{20}$ which hold that recognition on the basis of the full faith and credit clause must be given to ex parte divorces of sister states, provided that the party seeking the divorce is domiciled in the granting state at the time of the rendition of the decree. ${ }^{30}$ But the jurisdictional finding on which the decree is based (i.e., that plaintiff is domiciled in the state where action is brought) is subject to collateral attack; and if either the defendant ${ }^{31}$ or some other interested party ${ }^{82}$ succeeds in proving in the courts of another state that the plaintiff was not domiciled in the granting state, the divorce decree will not be entitled to recognition on the basis of the full faith and credit clause.

But what does this have to do with the validity of the decree as such, or the law under which the decree was rendered? It is obvious

necticut rendered under the circumstances stated was not entitled to obligatory cnforcement in the State of New York by virtue of the full faith and credit clause."

${ }^{27}$ See Cook, Is Haddock v. Haddock Overruled?, 18 IND. L.J. 165 (1943), suggesting that all Haddock was intended to establish was that while the civil status portion of the marital union could be severed by a state having jurisdiction by virtuc of domicile over one party but no jurisdiction whatever over the other, the property, or alimony, portion could not be so severed without jurisdiction over the party who stood to lose by the divorce. This prophetic view is now law. See Estin v. Estin, 334 U.S. 541 (1948).

${ }^{28}$ Dicey's note on the case starts as follows: "The profound respect rightly entertained by all English lawyers for the Supreme Court of the United States makes it inpossible to read the full report of Haddock ... . with any other fecling than that of sheer amazement." 22 L.Q. REv. 237 (1906). Beale ended his comment on it as follows: "The decision then is opposed to reason, to authority, and to morality. . .." He considered it worse than the Dred Scott or Legal Tender decisions. Beale, Constitutional Protection of Decrees for Divorce, 19 HARv. L. REv. 586, 597 (1906).

${ }^{29}$ Williams v. North Carolina (I), 317 U.S. 287,304 (1942), reversing State v. O. B. Williams and Lillie Shaver Hendrix, 220 N.C. 445,17 S.E.2d 769 (1941), herein referred to as Williams I; Williams v. North Carolina, 325 U.S. 226 (1945), affirming 224 N.C. 183,29 S.E.2d 744 (1944), herein Williams II. For an exhaustive discussion, particularly of Williams II, see Powell, And Repent at Leisure, 58 HARv. L. REv. 930 (I945).

${ }_{317}$ U.S. 287,303 (1942) (Williams I); 325 U.S. 226, 229-230 (1945) (Williams $I I$ ).

${ }^{31}$ Esenwein v. Coinmonwealth ex rel. Esenwein, 325 U.S. 279 (1945).

${ }^{32}$ Thus, Williams $I I$ upheld the conviction for bigamous cohabitation of two parties who, after leaving their respective spouses in North Carolina, where they had been living, went to Nevada, obtained ex parte divorces, intermarried, and returned to North Carolina. "The State of domiciliary origin should not be bound by an unfounded, even if not collusive, recital in the record of a court of another State." 325 U.S. 226 , 230 (1945) (Williams II). 
that if a decree is entitled to full faith and credit, it is not in violation of the due process clauses. The Constitution will not order what the Constitution forbids. But does it follow that a decree not entitled to recognition on the basis of the full faith and credit clause in sister states is also void as in violation of the due process clauses, ergo void even in the state of rendition? There are strong hints in recent decisions that the answer is in the negative.

Invalidity throughout the United States, in the opinion of Judge Goodrich, ${ }^{33}$ follows from the plain statement of the Supreme Court in the second Williams case that

Under our system of law, judicial power to grant a divorcejurisdiction, strictly speaking-is founded on domicil. The framers of the Constitution were familiar with this jurisdictional prerequisite, and since 1789 neither this Court nor any other court in the English-speaking world has questioned it. ${ }^{34}$

Leaving aside for a moment severe doubts as to the historical accuracy of that statement, ${ }^{35}$ one cannot help noticing two things. First, Williams II merely involved the full faith and credit, and not the due process, clause. Second, the portion of Mr. Justice Frankfurter's opinion quoted above by no means represents the view of the majority of the Supreme Court, even in the second Williams case. The concurring opinion, equally supported by three Justices, bluntly states:

The State of Nevada had unquestioned authority, consistent with procedural due process, to grant divorces on whatever basis it sees fit to all who meet its statutory requirements. It is entitled,

\footnotetext{
${ }^{33}$ Alton v. Alton, 207 F.2d 667, 676 (3d Cir. 1953).

${ }^{34} 325$ U.S. 226, 229 (1945).

${ }^{35}$ See the dissenting opinion of Hastie, J., in the Alton case, 207 F.2d $667,68 \mathrm{I}-2$ (3d Cir. 1953); also Cook, op. cit. sulpra note 27, at 166-169. A thorough historical study of the subject is still lacking, but it might be pointed out that Scots courts have granted a series of divorces in the I $g$ th century merely on the basis of adultery having been committed in Scotland, and in the absence of domicile of either party. ERSKINE, INSTITUTE OF THE LAW OF SCOTLAND 137 n. I (revised ed. 1838 ), while English courts have, on the basis of the Matrimonial Causes Act of 1857 , at least up to 1878 granted divorces to residents who were not domiciliaries. See Niboyet v. Niboyet, 4 P.D. I (C.A. 1878 ), reversing Phillimore's judgment below, 3 P.D. 52 ( 1878 ). The rule conditioning divorce upon domicile was not established firmly until the decision of the Privy Council in Le Mesurier v. Le Mesurier, [1895] A.C. 517 (P.C.). Curiously enough, Dicey's 1896 edition states the law of England to be substantially unsettled on this point, although the author admittedly adheres to the domicile theory. DICEY, Conflict of LAWS 269-276; 753-759 (Am. ed. by Moore 1896). For a recent broadside attack on Mr. Justice Frankfurter's statement quoted in text at note 34 , see David-Zieseniss v. Zieseniss, 129 N.Y.S.2d 649, 653-654 (Sup. Ct. 1954).
} 
moreover, to give its divorce decrees absolute and binding finality within its borders.

But if Nevada's divorce decrees are to be accorded full faith and credit in the courts of her sister states it is essential that Nevada have proper jurisdiction over the divorce proceedings. This means that at least one of the parties to each ex parte proceeding must have a bona fide domicile within Nevada for whatever length of time Nevada may prescribe. ${ }^{36}$

The two dissenting opinions, particularly that of Mr. Justice Rutledge, ${ }^{37}$ also point out that even Mr. Justice Frankfurter's majority opinion does not hold that the decree, successfully impeached on jurisdictional grounds in North Carolina for the purpose of refusing it full faith and credit there, is, therefore, void in Nevada. ${ }^{38}$ Consequently, it appears that Williams II does not hold that a divorce granted in the absence of jurisdiction over at least one of the parties based on domicile is void even in the state of rendition. This conclusion, at least so far as its present importance is concerned, is fortified both by the fact that $\mathrm{Mr}$. Justice Frankfurter's position, quoted above, has forced him into the minority in subsequent cases, ${ }^{39}$ and by the fact that the decision he primarily relies on has later been expressly overruled. ${ }^{40}$ Thus, it might easily be concluded that, even absent any parallel trend in the field of "normal" divorces, the Supreme Court would, if squarely faced with the question, hold that a divorce not grounded on jurisdiction by virtue of domicile over at least one of the parties, while not entitled to full faith and credit in sister states, is nevertheless valid in the state of rendition. This has been the express conclusion of the Seventh Circuit; ${ }^{41}$ and the Supreme Court, while reversing that decision on other grounds, has not seen fit to disaffirm it. ${ }^{22}$

A brief look into the field of "normal" divorces (i.e., where the court granting the decree has personal jurisdiction over both parties) will show that in this field, at least, domicile of one of the parties within the

\footnotetext{
${ }^{30} 325$ U.S. 226, 239 (1945).

${ }^{37} I d$. at 244 .

${ }^{38}$ See also Black, J., dissenting, id. at $26 \mathrm{I}, 262$.

${ }^{30}$ Cf. his dissent in Sherrer v. Sherrer, 334 U.S. $343,356-377$ (1948).

${ }^{40}$ Andrews v. Andrews, 188 U.S. 14 (1903); cf. Sherrer v. Sherrer, silpra note 39

${ }^{41}$ Sutton v. Leib, 188 F.2d 766,768 (7th Cir. 195I): "We have searched the numerous cases decided by the Supreme Court of the United States on the subject of migratory divorce for a definitive holding as to the judicial status of such divorce in the state that decreed it. It appears to be assumed that the decree is valid and binding in the state where it was rendered."

${ }^{42}$ Sutton v. Leib, 342 U.S. 402 (1952).
} at $352-353$. 
jurisdiction of the court granting the decree is not even a prerequisite for clothing that decree with effectiveness on the basis of the full faith and credit clause. The Supreme Court has long held that where a party to a divorce proceeding unsuccessfully contests the jurisdiction of the court where action is brought, he is bound by the determination of the court that it has jurisdiction and cannot later attack the decree collaterally. ${ }^{43}$ One might think that this is only true where two basic conditions are met: (I) if the law of the state granting the divorce actually requires that at least one of the parties be domiciled within its borders; and (2) where there is an actual contentious proceeding involving the fact of such domicile. Then the issue involved would be a jurisdictional fact, and since there must be an end to litigation somewhere, there could be little objection against making the court's determination that it has jurisdiction binding upon the parties and those in privity with them. ${ }^{44}$ But the Supreme Court has not remained within such narrow bounds. It has held that all divorce decrees granted by the courts of sister states are, if the other party as much as appeared by counsel, entitled to recognition under the full faith and credit clause. ${ }^{45}$ Of course, the parties themselves are estopped from impeaching the decree on jurisdictional grounds in collateral proceedings, but even persons not party to the proceedings nor in privity with them are so barred, and this in cases where the record indicates lack of domicile of plaintiff so clearly that to question the spuriousness of it would be an insult to adult intelligence. ${ }^{46}$

When a divorce cannot be attacked for lack of jurisdiction by parties actually before the court or strangers in the rendering

${ }^{43}$ Davis v. Davis, 305 U.S. 32 (1938).

4A Baldwin v. Iowa State Traveling Men's Ass'n, 283 U.S. 522, 525-526 (x93I): "Public policy dictates that there be an end to litigation; that those who have contested an issue shall be bound by the result of the contest, and that matters once tried shall be considered forever settled between the parties. We see no reason why this doctrine should not apply in every case where one voluntarily appears, presents his case and is fully heard, and why he should not, in the absence of fraud, be thereafter concluded by the judgment of the tribunal to which he has submitted his cause." See also Treinies v. Sunshine Milling Co., 308 U.S. 66, 78 (1939).

${ }^{40}$ Cook v. Cook, 342 U.S. 126 (x95I), reversing 117 Vt. 173,86 A.2d 923 (1952); Johnson v. Muelberger, 340 U.S. 58 I (1951); Coe v. Coe, 334 U.S. 378 (1948); Sherrer v. Sherrer, 334 U.S. 343 (1948); see also Drinkwater v. Drinkwater, III F.Supp. 559 (D.D.C. I953).

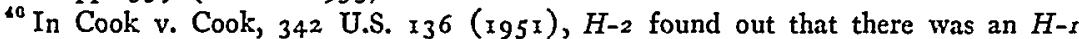
living. He thereupon sent $W$ to Florida to get a divorce from $H-r$, paying her expenses. $W$ obtained the divorce and returned to $H-2$ who thereupon remarried her. Since $H-r$ had appeared in the Florida action, the end result is that the divorce and the second marriage are both good. See Mr. Justice Frankfurter's acid dissent, 342 U.S. $126,129-133$ (195I). 
state, it cannot be attacked by them anywhere in the Union. The

Full Faith and Credit Clause forbids. ${ }^{47}$

Applying the doctrines of the Supreme Court with respect to both types of divorces to the Virgin Islands statute held unconstitutional, one cannot help observing two things: (I) If an ex parte divorce were granted under the first portion of Section 9a, making six weeks' physical presence in the Virgin Islands prima facie evidence of domicile, it would be subject to collateral attacks in other jurisdictions, since, under the rule of Williams II, the jurisdictional finding in an ex parte divorce is subject to collateral attack. ${ }^{48}$ Even if successfully attacked, however, the divorce would still be valid in the Virgin Islands. Since valid there, it cannot be unconstitutional under due process. (2) If, on the other hand, a divorce is granted under the second portion of the statute (requiring appearance of the other party), then the decree will be as invulnerable throughout the United States as can possibly be desired, not being subject to collateral attack anywhere else by anyone not entitled to attack it collaterally in the Virgin Islands. The curious result is that in the Alton case, where both $H$ and $W$ were subject to the jurisdiction of the court in which the divorce proceedings were brought, a different decision on the district court level would have produced an ironclad decree, safe even from the paternal control of the Third Circuit, since obviously neither party would have appealed. Since a statute under which valid decisions can be rendered is not unconstitutional, it is submitted that the Third Circuit's decision in Alton v. Alton was not correct.

\section{Consequences}

If, however, the Supreme Court had upheld the decision of the Court of Appeals for the Third Circuit without substantially modifying it, it is submitted that the divorce laws and decrees of several states would also have been subject to grave constitutional attack. Take, for instance, the laws of the two primary "havens" for migratory divorces, Florida and Nevada. Florida merely provides that ". . . in order to obtain a divorce the complainant must have resided ninety days in the State of Florida before filing the bill of complaint." ${ }^{\text {"40 }}$ When the Governor signed the law reducing residence requirements from one year to three months and enacting the provision quoted, he declared:

Florida is a transient state, extending to the people of the United States an invitation to come here as visitors and remain as resi-

\footnotetext{
${ }^{17}$ Johnson v. Muelberger, 340 U.S. 58 I, 589 (195I).

${ }^{48}$ For a successful attack on an ex parte Virgin Islands divorce, see Bean v. Bean, 95 N.Y.S.2d 477 (Sup. Ct. 1950).

${ }^{49}$ FLA. STAT. \& 65.02 (194I).
} 
dents. If this bill brings additional residents or visitors to Florida, it will be in line with that invitation (emphasis added).$^{50}$

Nevada assumes jurisdiction to grant divorces if "plaintiff shall have resided six weeks in the state before suit is brought." Ni Neither statute contains the slightest reference to "domicile;" but appellate courts have generally held that mere sojourn for the purpose of obtaining a divorce supposedly is not sufficient.52. Thus, "residence," as used in the statutes quoted above, has come to mean "legal residence," but not necessarily domicile. Furthermore, standards for the establishment of legal residence for divorce purposes are somewhat lax both in Florida and in Nevada. (The Supreme Court of Florida has said, "After all, the best proof of one's domicile is where he says it is." ${ }^{\text {"53 }}$ ) It might also be pointed out that the peculiar feature of ex parte divorces is that they do not, as a rule, become subject to appeal in the state of rendition, so that even state supreme courts' interpretation of statutory jurisdictional prerequisites will not necessarily be followed. The following testimony, for instance, sufficed to establish Mrs. Hendrix's legal residence in Nevada for the purpose of obtaining her ill-fated divorce enabling her to marry Mr. Williams of Williams I and II fame:

Q. [by her counsel] Where do you reside?

A. Las Vegas, Nevada.

Q. Las Vegas, Clark County, Nevada?

A. Yes.

Q. You filed your complaint on June 26th, 1940, had you resided here a full six weeks prior to that time?

A. Yes.

Q. When did you come to Clark County, Nevada?

A. May I5, I940.

Q. What was your object and intention in coming here at that time?

A. To establish a residence.

${ }^{50}$ Quoted by Willock, Historical Review of the Divorce Lawe of Florida, 5 FLA. ST:.T. ANN. 53I, 54I (1943).

${ }^{51}$ NEv. COMP. L., SUPP. 1931-194I $\$ 9460$.

52 Kutner v. Kutner, 159 Fla. $870,873-4,33$ So.2d 42 (1947) and cases there cited; in the Kutner case the Supreme Court of Florida reversed a circuit court "mail order" divorce decree. See also Blouin v. Blouin, 67 Nev. 314, 218 P.2d 937 (1950); Latterner v. Latterner, 5 I Nev. 285, 274 Pac. 194 (1929); Lewis v. Lewis, 50 Nev. 419, 264 Pac. 981 (1928); Presson v. Presson, 38 Nev. 203, 147 Pac. 1081 (1915). For historical background, see In re Schnitzler, 33 Nev. 58 I, I I2 Pac. 848 (I9II), and Ingram and Ballard, The Business of Migratory Divorce in Nevada, 2 LAW \& CoNTEMP. PROB. 302 (1935).

${ }^{63}$ Ogden v. Ogden, 159 Fla. 604, 609, 33 So.2d 870, 873 (1947). 
Q. Did you establish a residence?

A. Yes.

Q. And that residence was an indefinite permanent residence? (Emphasis added.)

A. Yes.

She also testified that she had not been absent for a twenty-four hour period during the time specified, and that she lived at the Alamo Court, apparently a motel. There was no cross-examination. ${ }^{\text {54 }}$

A cursory check of annotations of the full faith and credit clause will demonstrate the well-known fact that most divorce decrees successfully impeached collaterally in other states for lack of jurisdiction in the granting state were granted by Florida and Nevada. If one were to follow Judge Goodrich's view that the due process and full faith and credit clauses are correlative, one could hardly escape the conclusion that these decrees were based on statutes constantly and notoriously administered in an unconstitutional manner and therefore unconstitutional. ${ }^{55}$ If the Virgin Islands cannot make six weeks' presence within her borders merely prima facie evidence of domicile, it is difficult to conceive of how Nevada can grant divorces on the basis of a statute requiring six weeks' physical presence and nothing more. If the saving grace of the Nevada practice is the sort of thing that made Mrs. Hendrix's counsel ask her, "And that residence was an indefinite permanent residence?" and made her answer yes, then the constitutionality of statutes becomes conditioned upon the extent of perjury permitted by the courts administering them.

\section{Consequences of a Reversal}

If the doctrine of the majority in the Alton case should eventually be repudiated by higher authority, and if divorces of the Alton type are granted in the future, as being in accordance with the requirements of due process, there remains the question of the validity of the decrees against collateral attack (or the question of full faith and credit) particularly by the state of original domicile in a prosecution for bigamy or some similar offense if one of the parties should remarry. Whether the rule of Johnson v. Muelberger, ${ }^{5 B}$ that parties not entitled to attack a "normal" divorce in the state of rendition cannot attack it elsewhere, bars such prosecution is an unresolved dilemma. Judge Goodrich apparently thinks that it does not; ${ }^{57}$ but since a divorce obtained in com-

\footnotetext{
5. Transcript of Record, pp. 40-4x, State v. Williams and Hendrix (II), 224 N.C. I 83,29 S.E.2d 744 (I 944 ).

${ }^{55}$ Yick Wo v. Hopkins, $1 \times 8$ U.S. 356 (1886).

56 340 U.S. $58 x$ (195x).

${ }^{57}$ Cf. Alton v. Alton, 207 F.2d 667, 674 ff. (3d Cir. 2953 ).
} 
pliance with Section 9a of the Virgin Islands act is presumably not subject to collateral challenge in the Virgin Islands by anyone, it would, under a literal interpretation of the rule just stated, be immune to attack by anybody in other jurisdictions. In this connection, it should be noted that most convictions for bigamy, bigamous cohabitation and the like, involving collateral attack on a foreign divorce, concern ex parte divorces. 58

There is, however, eminent, if not too recent, authority to the effect that the state as the third party to the marriage cannot be precluded from asserting its continuing validity merely because the parties themselves are precluded from so doing. ${ }^{59}$ The notion that the domiciliary state has too intimate an interest in the marital status of its citizens to permit their evading its laws by procuring divorces in other jurisdictions might be too deeply rooted in legal thinking to be dislodged without a major struggle. It is, to be sure, entirely illogical, for the same states that jealously guard their right to refuse recognition to foreign ex parte divorces recognize without question the evasion of their own marriage laws by their citizens repairing abroad to procure marriages they cannot obtain at home, be it because of affinity, ${ }^{60}$ or judicial decree. ${ }^{61}$ But even if the Johnson rule is read subject to the ex-

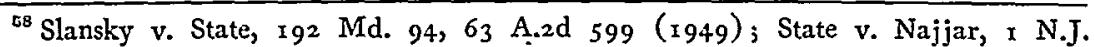
Super. 208, 63 A.2d 807 (1949), aff'd, i N.J. 208, 66 A.2d 37 (r949); Reed v. State, $\mathrm{r}_{4} 8$ Tex. Cr. 409 , 187 S.W.2d 660 (1944); State v. Westmoreland, 76 S.C. 145, 56 S.E. 673 ( 1907 ); State v. Armington, 25 Minn. 29 ( 1878 ) ; People v. Baker, 76 N.Y. 78 (1879); Hood v. State, 56 Ind. $263,269-270$ (1877). The latter case seems to mark the premiere of mail order divorces; the one impeached was rendered by Utah. The court said: "The divorce manifestly was granted in violation of the sovereignty and jurisdiction of another state, and in violation of the plainest principles of international and constitutional law."

${ }^{60}$ People v. Dawell, 25 Mich. $246(1872)$, by Judge Thomas Cooley. This is a 2 to $x$ decision upholding defendant's conviction for bigamy, although his $W-I$ had obtained an Indiana divorce from him and he had appeared. Both defendant and $W_{-I}$ were found to be residents of Michigan by the Michigan trial court. As Judge Cooley tersely expressed the issue: "Does the State of Michigan establish and control the domestic relations of its own citizens, or do they exist and continue only at the discretion of the inferior courts of another State?" Id. at 253. Campbell, J., dissenting, thought that the Indiana decree should be entitled to full faith and credit. $I d$. at $265 \mathrm{ff}$.

${ }^{\circ 0}$ In re May's Estate, 305 N.Y. 486, 114 N.E.2d 4 (1953) : decedent had married his half-niece in Rhode Island, where such marriage was legal, and lived with her in New York, where it was not. Held: the marriage celebrated in Rhode Island, if valid there, is valid in New York, too.

${ }^{0 x}$ Fisher v. Fisher, 250 N.Y. $3 \times 3, \times 65$ N.E. $460\left(x_{929}\right): H$ had been the guilty party in a New York divorce proceeding; and the decree prohibited his remarriage while his wife was still alive. He nevertheless remarried in another jurisdiction (to wit, on board a ship, 40 miles out from the port of New York). In an action for separation by his second wife, held, the second marriage is valid. 
ception that the state of original domicile is not barred from asserting the validity of the original marriage by collaterally attacking the divorce on jurisdictional grounds, although everybody else is precluded from so doing, it might be worth noting that in the present case, such prosecution would not be possible if the remarrying party remarried in the Virgin Islands. ${ }^{62}$ Furthermore, as has been pointed out in connection with the Williams cases, the mere possibility of subsequent successful collateral attack would not impugn the constitutionality of the original decree in the state of rendition, but merely its claim to full faith and credit in the attacking jurisdiction. For all we know, Mr. Williams and Mrs. Hendrix are still validly married in Nevada.

\section{Consensual Divorce and Due Process}

Even if the basic premises of the majority opinion in Alton v. Alton are granted, there remains one curious difficulty which does not seem to have been convincingly overcome. Suppose that the statute does violate the due process clause. Who is being deprived of due process? $H$, we take it, is not complaining; he did not argue in support of the decision which in fiction went in his favor when $W$ appealed from it. Even if $H$ were actually complaining, it might be of interest to ascertain if he is being deprived of "life" (certainly not); "liberty" (which is being restored to him as well as to $W$ ); or "property." Obviously, it could only be the last, a startling thought in this day and age. It might safely be predicted that no court will now hold that a husband has a property interest in his wife within the meaning of the Fifth Amendment; and as to the property interest of the wife in the continuation of the marital nexus, the Supreme Court has held that the latter is not suspended even by a valid ex parte divorce. ${ }^{63}$

In attempting to bring the statutory divorce procedure of the Virgin Islands within the purview of the due process clause, Judge Goodrich, fully cognizant of the difficulty of protecting by that clause some-

${ }_{3}$ GEN. STAT. CONN. $\$ 85+6$ (19+9): "Any person who shall marry another, if either be then lawfully married, or shall marry in another state or conntry in violation of the laws thereof, and shall knowingly cohabit and live with such other in this state as husband and wife, shall be imprisoned not more than five years" (emphasis added). Connecticut does not have a "strong" public policy against migratory divorces; it has traditionally both granted and recognized ex parte decrees. See Haddock v. Haddock, zor U.S. 562 (1906); Gildersleeve v. Gildersleeve, s8 Conn. 689, 92 Atl. $68_{4}\left(\mathrm{rgr}_{4}\right)$. It does, however, fully permit collateral attacks on such foreign divorce decrees. Rice v. Rice, ${ }_{34}$ Conn. 44o, 58 A.2d 523, 527 (1948), aff' $d, 336$ U.S. 674 (1949); Santangelo v. Santangelo, 137 Conn. 404, $7^{8}$ A.2d 245, 246 (1951), cert. denied, 34 I U.S. 927 (1951); State v. Cooke, 110 Conn. 348 , 148 Atl. 385 (1930). The last case involved a prosecution for nonsupport.

${ }^{63}$ Estin v. Estin, 334 U.S. 541 (1948). 
one who does not want to be so protected, suggests that the case is analogous to an attempt to confer jurisdiction over collision at sea on a state court in the absence of objection. ${ }^{64}$ The analogy seems to be somewhat incomplete, since conferring admiralty jurisdiction on an inland state would not violate the due process clause, but would violate specific mandates in other sections of the Constitution and acts of Congress enacted in accordance therewith. ${ }^{65}$

Yet, there conceivably is one way of making out a case for deprival of something without due process of law in the Alton case. That would be that the parties, in collusion with each other, deprive the state of Connecticut of its right to regulate their marital status. On a larger scale, it would also be the deprivation of the state of domiciliary origin of its right to prosecute for bigamy and like offenses those who, by collusively invading more liberal jurisdictions, obtain a quick release from marital bonds good against the whole world under the Johnson rule and then, having found greener pastures, marry other parties and return home. But the various due process clauses protect only persons, ${ }^{68}$ not states. Whether a dictum in a recent case that "The people of the State are also entitled to due process of law" as corporations were held to be persons within the purview of the due process clauses, ${ }^{68}$ states will now also be considered as persons, seems to be a totally unresolved, and even less interesting, question. For in cases like Alton v. Alton, states would be denied "due process" because the Constitution requires them to extend full faith and credit-an impossible construction.

Thus the outcome is a series of paradoxes:

(I) If the decree had been granted in the Alton case, it would have been entitled to full faith and credit under the Constitution, but the law under which it was sought is held to be unconstitutional because it violates the due process clause.

\footnotetext{
'Alton v. Alton, 207 F.2d 667,677 (3d Cir. 1953).

os U.S. Const. ART. III, $\S_{2}$ : "The judicial Power shall extend ... to all Cases of admiralty and maritime Jurisdiction. ..." 28 U.S.C. $\$ 1333$ (Supp. 1952) : "The district courts shall have original jurisdiction, exclusive of the courts of the States, of ... [a]ny civil case of admiralty or maritime jurisdiction, saving to suitors all other remedies to which they are otherwise entitled." The construction of the latter so-called "saving clause" seems to be that federal jurisdiction in rem is exclusive while the state can exercise jurisdiction over in personam actions as long as they do not change substantive maritime law. Madruga v. Superior Court, 346 U.S. 556, 560-56r (1954); RobINSON, ADMIRALTY $\$ 4,22-24$ (1939).

${ }^{00}$ Cf. note 8 supra.

${ }^{07}$ Stein v. New York, 346 U.S. ${ }_{56}$, 197 (1953).

${ }^{88}$ The first case to so hold was Santa Clara County v. Southern Pacific R.R., I I 8 U.S. 394,396 (1886).
} 
(2) Neither party attacks the law on that basis; and both would be very happy if the decree were granted. Nevertheless, someone is being deprived of due process.

(3) If the state of domiciliary origin can prosecute $H$ and $W$ for bigamy if they should remarry other parties and return home, it is not being deprived of due process. If it cannot so prosecute them, the processes available to it for the regulation of the marital status of its domiciliaries will be seriously curtailed, but that will be because ". . the Full Faith and Credit Clause forbids."

Hans W. BAade

Donald E. Williams

\footnotetext{
${ }^{69}$ Johnson v. Muelberger, 340 U.S. $5^{81}, 5^{89}$ (r95r).
} 